\title{
Die sigbaarheid van vertaaldheid in resensies van vertaalde Engelse en Afrikaanse romans
}

\author{
Lelanie de Roubaix \\ Departement Afrikaans en Nederlands, Universiteit Stellenbosch \\ E-pos: lelaniederoubaix@gmail.com
}

\author{
Amanda Lourens \\ Departement Afrikaans en Nederlands, Universiteit Stellenbosch \\ E-pos: alourens@sun.ac.za
}

\section{Opsomming}

Die neiging in die literêre kritiek om vertaalde werke as "oorspronklike" werke te resenseer, is alreeds deur verskeie navorsers ondersoek (sien byvoorbeeld Lambert 2010, Maier 2008, Paloposki 2012, en Schulte 2015). Dit beteken dat resensies baie selde daarvan melding maak dat die teks in der waarheid 'n vertaling is. Hierdie neiging van die kritiek om vertaalde tekste as "oorspronklik" te hanteer, is problematies. Vertalers en vertalings kan sodoende gemarginaliseer word, met negatiewe gevolge vir die vertaalprofessie sowel as vir die kanonisering van vertaalde romans (Leech 2005: 12). Vertalings en vertalers word voorts aan haas onmoontlike standaarde onderwerp, omdat resensente dikwels nie vertroud met vertaling is nie, en sodoende die nie-erkenning daarvan in die hand werk.

Die studies waarna reeds verwys is, is in Europa uitgevoer, sodat daar ruimte is vir ' $\mathrm{n}$ soortgelyke studie in die Suid-Afrikaanse konteks. In hierdie studie val die fokus op resensies van vertaalde romans wat tussen 2006 en 2015 in Suid-Afrika gepubliseer is. Die ontleding sal lig werp op die vraag na die mate waartoe die vertaler en vertaalhandelinge in resensies sigbaar raak, en derhalwe of die resensering van vertaalde werke as oorspronklikes ook binne die Afrikaanse en Suid-Afrikaanse Engelse literêre sisteem plaasvind.

\begin{abstract}
The tendency to review translated texts as "original" works has been studied by various scholars in literary criticism (see for example Lamber 2010, Maier 2008, Paloposki 2012, and Schulte 2015). This means that reviews very seldom mention that the reviewed work is in fact a translation. This tendency to treat translated texts as "originals" in literary criticism is problematic. It can cause translators as well as translation to be marginalised, with negative
\end{abstract}


consequences for the translation industry as well as the canonisation of translated novels (Leech 2005: 12). Furthermore, translations and translators are subjected to virtually impossible standards when reviewers are not familiar with translation and consequently reinforce the nonrecognition of translated works.

The research referred to above was conducted in Europe, and there is a need for similar research in the South African context. This study focuses on reviews of translated novels published in South Africa between 2006 and 2015. The analysis examines the degree to which the translator and translational acts are visible in reviews, and therefore whether translated texts are also reviewed as originals in the Afrikaans and South African English literary system.

Sleutelwoorde: vertaling; onsigbaarheid; resensering; Afrikaanse literêre sisteem; SuidAfrikaanse Engelse literêre sisteem

\section{Inleiding 1}

Internasionaal blyk daar 'n tendens te bestaan om vertalings as "oorspronklike" werke te resenseer (Lambert 2010, Maier 2008, Nord 1991, Paloposki 2007, Paloposki 2012, Reiss 2000, Schulte 2015). Dit wil sê, resensies van vertalings maak tipies glad nie, selde of net vlugtig (en oppervlakkig) daarvan melding dat die teks onder bespreking 'n vertaling is. Navorsing wat byvoorbeeld in Engeland (vergelyk Fawcett 2000), Frankryk (vergelyk Vanderschelden 2000) en Finland (vergelyk Koskinen en Paloposki 2003) oor hierdie onderwerp gedoen is, bevestig telkens hierdie verskynsel (vergelyk ook Paloposki 2012: 187). Verder maak Reiss (2000: 2) die volgende stelling oor die kwessie:

$[R]$ eviews of translations do not usually judge them as translations at all. And when they do, it is usually only in passing and with such pirate phrases as 'translated fluently', 'reads like the original', 'excellent translation' or 'sensitively translated' - judgements that are almost always vague and unsupported.

Hierdie tendens om vertaalde werke as "oorspronklike" werke te resenseer, is om verskeie redes problematies. Volgens Leech (2005: 12) kan dit byvoorbeeld veroorsaak dat vertalers en vertalings (verder) gemarginaliseer word: Dit kan negatiewe implikasies inhou vir onder meer die kanonisering ${ }^{2}$ van vertaalde romans sowel as vir die vertaalprofessie. Leech (2005: 12) voer verder aan dat vertalings en vertalers aan onbillike standaarde gemeet word omdat resensente oor die algemeen onkundig is oor wat vertaling behels en dat dit gebrekkige erkenning in die openbare domein tot gevolg kan hê. Hierdie "onsigbaarheid" in die media skep die persepsie by die publiek dat vertalings en vertalers lae status het wat kan veroorsaak dat vertalings nie gekanoniseer word nie en dat jongmense nie die vertaalprofessie betree nie (vergelyk McLaughlin 2008, Venuti 2008: 13).

\footnotetext{
${ }^{1}$ Hierdie artikel is gebaseer op 'n navorsingsprojek wat in 2017 aan die Departement Afrikaans en Nederlands aan die Universiteit Stellenbosch as deel van die honneursprogram in vertaling voltooi is.

${ }^{2}$ Die term "kanon" word gedefinieer as "'n versameling van werke en outeurs wat deur 'n sosiale groep of literêre kring as waardevol erken word" (Moerbeek 1992: 342).
} 
In hierdie artikel sal daar vanuit 'n vertaalteoretiese hoek ondersoek ingestel word of die problematiese tendens dat resensies van vertalings glad nie, selde of net baie vlugtig en oppervlakkig daarvan melding maak dat die teks 'n vertaling is, ook plaaslik in die SuidAfrikaanse literêre sisteem bespeur kan word. In die onderafdeling wat volg, kom 'n literatuuroorsig aan bod wat die grondslag bied vir die daarstel van 'n meetinstrument vir die praktiese ontleding van resensies (vergelyk afdeling 3) sowel as die interpretasie van die resultate wat met behulp van die meetinstrument verkry is (vergelyk afdelings 4 en 5). Uiteindelik, in afdeling 6, kom die studie tot 'n gevolgtrekking gebaseer op sowel die kwalitatiewe as kwantitatiewe ontleding van die data.

\section{Literatuuroorsig}

\subsection{Die "onsigbaarheid" van die vertaler}

Die term "onsigbaarheid" word deur die Amerikaanse vertaalteoretikus Lawrence Venuti in sy seminale publikasie getiteld The Translator's Invisibility (1995, 2008) gebruik. "Onsigbaarheid" verwys na die mate waartoe bepaalde vertaaltradisies die teenwoordigheid van die vertaler in vertalings duld (Hatim 2001: 45). Venuti gebruik die term om twee verwante kwelpunte binne die vertaalstudie te illustreer.

In die eerste instansie verwys hierdie term na die randposisie wat vertaling in die AngloAmerikaanse literêre tradisie beklee, te wete dat vertalings as ondergeskik aan en minder belangrik as die brontekste, oftewel die "oorspronklike" tekste, beskou word. Gevolglik word vertalings dikwels as oorspronklike tekste voorgehou deur die vertaler se rol as mede-produsent te misken of ignoreer, byvoorbeeld in resensies of op boeke se voorblaaie (Emmerich 2013: 200, Munday 2001: 144, Venuti 2008: 1). In die tweede plek verwys die term "onsigbaarheid" na die mate waartoe 'n literêre vertaling vloeiendheid ("fluency") suggereer. Venuti (2008: 5) beskryf'n "vloeiende" vertaling soos volg: "immediately recognizable and intelligible, 'familiarised', domesticated, not 'disconcertingly' foreign [and] capable of giving the reader unobstructed 'access to great thoughts', to what is "present in the original" [ons kursivering]. Hierdie beskrywing word soos volg deur Venuti (2008: 5) saamgevat en verder verklaar: "The more fluent the translation, the more invisible the translator, and, presumably, the more visible the writer or meaning of the foreign text" [ons kursivering]. 'n Vertaling is dus "vloeiend" wanneer dit so te sê geen blyke van die vertaalproses toon nie en net soos die oorspronklike lees. Venuti (2008: 1) voer aan dat vloeiende vertalings deur die meeste uitgewers, resensente en lesers met geslaagdheid en aanvaarbaarheid vereenselwig word. "Onsigbaarheid" het dus te make met vertalers se taalgebruikskeuses sowel as die wyse waarop vertalings ontvang en beoordeel word, byvoorbeeld in resensies (Hatim 2001: 45). In hierdie studie is die fokus op laasgenoemde manifestasie van die "onsigbaarheid" van die vertaler in die resensies van vertalings.

In Venuti se toepassing van die term "onsigbaarheid" is vertalers grootliks self verantwoordelik vir die "sigbaarheid" of "onsigbaarheid" van hulle stem in die vertaalde teks afhangend van die vertaalstrategie(ë) wat hulle kies om te volg. Hierdie beskouing kontrasteer met Hermans (1996: 23) en McLaughlin (2008: 62-64) se siening dat die vertaler se stem altyd in 'n vertaling teenwoordig is selfs al lyk dit nie so nie. Luidens Venuti $(1995,2008)$ moet alle vertalers 'n keuse uitoefen tussen twee vertaalstrategieë, naamlik domestikering (“domestication") en vervreemding ("foreignisation"). Eersgenoemde is daarop gemik om 'n maklik verstaanbare vertaling wat vlot en maklik in die doeltaal lees, te produseer sodat die leser toegang het tot die presiese betekenis 
wat die skrywer wou oordra (Palumbo 2009: 48). Daarteenoor behels vervreemding dat die bronteks opvallend is in die doelteks eerder as om die "vertaaldheid" van die teks te probeer verberg ten einde die leeservaring meer verrykend te maak (Palumbo 2009: 48).

Venuti $(1995,2008)$ neem 'n kontroversiële standpunt in ten opsigte van die keuse tussen hierdie vertaalstrategieë (vergelyk Schäffner 1995: 8). Hy kritiseer die dominante Anglo-Amerikaanse literêre tradisie van domestikering wat vereenselwig word met "fluency" en "transparency" omdat dit na sy mening op twee maniere tot die "onsigbaarheid" van die vertaler kan bydra: In die eerste instansie, aangesien gedomestikeerde vertalings nie lesers se aandag daarop vestig dat die teks vanuit ' $n$ ander konteks oorgedra is nie en tweedens, aangesien domestikering kan veroorsaak dat vertalings "insmelt" by die inheemse tekste en dat lesers daarom voel hulle vind nie daarby baat om vertalings te lees nie omdat daar niks is wat dit van inheemse tekste onderskei nie (Hermans 2009: 98-99, Venuti 1995: 1, 5, 8, 18). Met ander woorde, deur' 'n vertaler se keuse om van domestikering as vertaalstrategie gebruik te maak, bewerkstellig vertalers gedeeltelik hulle eie "onsigbaarheid". Venuti argumenteer dus ten gunste van vervreemding ten einde die vertaler se sigbaarheid te verhoog en rig 'n pleidooi aan vertalers ('n sogenaamde "call to action") om vervreemding toe te pas (Hermans 2009: 99, Venuti 1995: 306).

In hierdie studie word die konsep "onsigbaarheid" op resensies van vertaalde romans toegepas. Daar word aangevoer dat indien resensente nalaat om in hulle resensies van 'n vertaalde teks erkenning te gee daaraan dat dit ' $n$ vertaling is, die resensent as die fasiliteerder van die vertaler se "onsigbaarheid" optree. Laasgenoemde dui op Lefevere (1992) se konsep "herskrywing".

\subsection{Herskrywing}

Lefevere (1992: 5) is van mening dat herskrywings soos resensies van groot belang is en nagevors behoort te word omdat dit in 'n bepaalde omgewing as oorspronklike tekste funksioneer, maar in der waarheid 'n gemanipuleerde beeld van 'n skrywer, 'n teks, 'n genre en selfs van die algehele literatuur van 'n tydperk aan lesers oordra. Boonop bereik herskrywings 'n veel groter gehoor vanweë onder meer aandag in die media. Resensente van vertalings beskik oor enorme mag in die beeldvorming van literatuur. Resensente is by magte om vertalings as nievertaalde, "oorspronklike" werke aan die publiek voor te hou deur nie te vermeld dat die teks ' $n$ vertaling is nie, en kan dus implisiete inligting oor byvoorbeeld die belangrikheid van vertaling en vertalers aan lesers oordra deur middel van die mate van aandag wat hulle aan hierdie aspekte skenk. Verder is resensente in die eerste instansie in die posisie om sekere tekste in die kollig te plaas en ander op die agtergrond te skuif, en tweedens om 'n stempel van goedkeuring of teenkanting op 'n publikasie af te druk. Vanweë resensente se betrokkenheid by onder meer hierdie prosesse van aanvaarding of verwerping van 'n literêre teks, beskou Lefevere (1992: 2) herskrywings as 'n magtige kanoniseringsinstrument. Volgens Lefevere is herskrywing, en dus kanonisering, onderworpe aan sekere beperkende en manipulerende sosiokulturele magte binne en buite die literêre sisteem (Palumbo 2009: 83).

'n Aantal aannames en konsepte staan sentraal binne Lefevere (1992) se herskrywingsteorie: Literatuur is 'n sisteem wat onlosmaaklik deel van die omgewing van 'n kultuur of samelewing is; taal is ' $n$ weerspieëling van kultuur; die literêre sisteem beskik oor 'n regulatoriese "liggaam", met verwysing na die term "professionals", ideologie en die beginsel van die patronaat; die literêre sisteem beskik oor 'n bepaalde gedragskode, 'n sogenaamde poëtika watter literatuur voorkom en hoe dit funksioneer (Palumbo 2009: 103); herskrywings is 
noodwendig gemanipuleerde beelde van die werklikheid; en die kanonisering (of marginalisering) van 'n teks is die uitvloeisel van al hierdie voorafgenoemde elemente. Met ander woorde, volgens Lefevere is elke besluit wat onder meer deur resensente en vertalers gemaak word, aan al hierdie sosio-kulturele faktore onderworpe en verklap daarom belangrike gegewens oor die herskrywer en sy konteks (Geldenhuys 2009: 42).

\subsection{Resensering en die polisisteemteorie}

Lefevere (1992: 6) beskou Itamar Even-Zohar se polisisteemteorie as 'n toepaslike raamwerk vir die bestudering van herskrywings. 'n Moontlike verklaring hiervoor is dat die proses van kanonvorming en die rol wat resensente in kanonisering speel van die sentrale aspekte binne dié teorie is. Volgens Even-Zohar is die literêre sisteem 'n polisisteem wat bestaan uit verskeie hiërargies geordende subsisteme: Daar is tekste in die sentrum, wat die kanon uitmaak, en tekste op die periferie (Even-Zohar 1990: 14, 27). Die stryd tussen die verskillende subsisteme, oftewel strata, is 'n stryd om kanonisering - met ander woorde, om in die sentrum te wees (Palumbo 2009: 84).

Even-Zohar se idee van die literatuur as 'n "sisteem" is ontleen aan die Russiese Formalisme wat reeds in die laat 1920's ontwikkel is (vergelyk Codde 2003: 92). Even-Zohar stem egter nie saam met die Russiese Formaliste se siening dat die literêre sisteem uit slegs sogenaamde "hoë" literatuur en "meesterstukke" (gekanoniseerde werke) behoort te bestaan nie. Volgens hom bestaan 'n literêre polisisteem ook uit "massaliteratuur" wat insluit "popular literature of all sorts, marginal and peripheral literature (such as "journalese" semi-literary texts), folktales, etc." - dit wil sê sogenaamde "lae" literatuur (niegekanoniseerde werke) (Even-Zohar 1990: 15; Gentzler 2001: 106). Even-Zohar gebruik die terme "niegekanoniseerd" en "gekanoniseerd" om te verwys na daardie literêre norme en werke wat deur die sogenaamde dominante kringe in 'n samelewing onderskeidelik verwerp en as legitiem aanvaar word (Even-Zohar 1990: 15). "Kanonisiteit" is dus nie 'n inherente eienskap van tekste nie, maar die gevolg van magsverhoudige binne 'n sisteem. Hierdie kwessie van "kanonisiteit" staan sentraal in EvenZohar se konseptualisering van polisisteme (soos die literêre sisteem) as hiërargies geordende strukture omdat dit veroorsaak dat gekanoniseerde en niegekanoniseerde sisteme in 'n voortdurende kompetisie met mekaar is. Die struweling tussen die verskillende sisteme binne 'n polisisteem word as universeel aan enige kulturele sisteem beskou (Roos 2009: 9).

Toegang tot die kanon word op verskeie maniere bewerkstellig. Dijkstra (1989) verdeel die praktyk van kanonvorming in 'n sogenaamde aktiewe en 'n passiewe komponent. Die aktiewe komponent behels die samestelling en oordrag van 'n kanon deur institusies soos resensering en akademiese studie. Die passiewe komponent hierteenoor verwys na die lesers wat op skool en deur boekebylaes van koerante met hierdie gekanoniseerde tekste in aanraking kom (Lourens 1997: 37-38). Resensente vervul die rol van "hekwagter" aangesien hulle 'n eerste keuse uitoefen met betrekking tot die totale aanbod van nuwe publikasies (Lourens 1997: 38). Hierna vervul hulle die rol van "meningsvormer" deur hulle keuse aan die leserspubliek oor te dra sowel as deur die uitsprake wat hulle in 'n resensie oor literatuur maak, byvoorbeeld die tref van vergelykings tussen skrywers. Die publiek gebruik resensies as riglyn by die keuse van boeke en ook as bevestiging van keuses en uitsprake wat deur die resensent gemaak is (Lourens 1997: 38). Resensente se keuses word verder uitgedun deur die akademiese kritiek, totdat 'n (voorlopige) kanon oorbly wat dan as vertrekpunt dien vir die samestelling van bloemlesings, skoolboeke en literatuurgeskiedenisse. 
Resensering is dus 'n noodsaaklike eerste fase vir verdere kanonisering (Lourens 1997: 38), en resensies vervul 'n sleutelrol in die beeldvorming oor literatuur - met ander woorde, in die bepaling van watter literêre werke gedurende 'n sekere tydperk tot die literatuur gereken word en watter posisie hulle op die literêre ranglys beklee. Lefevere (1985: 6) bevestig laasgenoemde met betrekking tot die resensering van spesifiek vertalings: "In order for a foreign writer to be accepted in a native system, translations of his/her work need to be supplemented by critical appreciations [...] within the potentially receiving system". Resensering in die hoofstroommedia word dus beskou as die eerste en deurslaggewende seleksieoomblik in die vorming van die literêre kanon: By gebrek aan resensies word 'n werk maklik oorgesien vir latere bespreking in akademiese kringe. Hierdie tendens blyk onder meer uit 'n grootskaalse studie wat in die negentigs deur Susanne Janssen in Nederland uitgevoer is: Sy het bevind dat die hoeveelheid aandag wat resensente aan 'n nuwe publikasie skenk ten nouste verband hou met die hoeveelheid aandag wat resensente vantevore aan vorige werke deur dieselfde skrywer gewy het (Janssen 1994). Janssen (1994: 195-196) noem hierdie verskynsel die "reproduksiemeganisme" en skryf dat dit mettertyd veroorsaak dat die resensering van slegs bepaalde werke 'n legitieme keuse is. Resensente beskik dus oor besonderse mag, ten spyte daarvan dat hulle onderworpe is aan sosio-kulturele faktore wat boonop voortdurend verander in ooreenstemming met die tydsgees (vergelyk byvoorbeeld Lefevere 1985).

\section{Probleemstelling en metodologie}

\subsection{Probleemstelling}

In hierdie artikel word ondersoek of die tendens dat resensies van vertalings glad nie, selde of net baie vlugtig en oppervlakkig daarvan melding maak dat die teks 'n vertaling is, ook plaaslik in die Suid-Afrikaanse literêre sisteem bespeur kan word. Met ander woorde, die kwessie binne die vertaalstudie rakende die "onsigbaarheid" van die vertaler en/of die vertaalhandeling (Venuti 1995, 2008) word in hierdie studie met betrekking tot die resensies van vertaalde werke ondersoek deur aan te voer dat resensente van vertaalde werke as fasiliteerders van 'n vertaler se "onsigbaarheid" optree indien hulle nalaat om in die resensie erkenning te gee aan die feit dat dit 'n vertaling is.

Vir hierdie doeleindes sal $\mathrm{al}^{3}$ die Afrikaanse en Engelse resensies van vertaalde romans met Afrikaans en Suid-Afrikaanse Engels as taalpaar wat gedurende die tydperk 2006 tot 2015 in/op geselekteerde koerante en aanlynplatforms verskyn het (49 resensies) ontleed word. Die ontleding geskied aan die hand van kwantitatiewe sowel as kwalititatiewe merkers in die resensies wat daarop dui of daarmee verband hou dat die roman 'n vertaling is. Binne die gekose teoretiese raamwerk sal daar lig gewerp kan word op moontlike redes vir en implikasies van die bevindinge, onder meer met verwysing na die status van vertaling en die huidige stand van die kanons van vertaalde werke.

\footnotetext{
${ }^{3}$ Let wel: Resensies van romans deur skrywers wat hulle eie werke vertaal (bekend as "selfvertalers") is nie by die data ingesluit nie aangesien hulle tipies nie as vertalers beskou word nie en hulle werke dus per implikasie nie as vertalings beskou word nie (vergelyk Hokenson en Munson 2007: 1-2). Sodanige werke sal daarom gewoonlik ook nie as vertalings geresenseer word nie.
} 


\subsection{Doelstelling}

Hierdie studie het dit eerstens ten doel om die sigbaarheid al dan nie van die vertaler en vertaalhandeling in die resensies van vertaalde romans met Afrikaans en Suid-Afrikaanse Engels as taalpaar vir die tydperk 2006 tot 2015 vas te stel. Met ander woorde, om te bepaal of, of tot watter mate, die internasionale verskynsel dat vertaalde werke geresenseer word sonder om te noem dat 'n werk 'n vertaling is, binne die Afrikaanse en Suid-Afrikaanse Engelse literêre sisteme voorkom. ' $n$ Verdere doelstelling is om te bepaal aan watter (tegniese) aspekte van vertalings resensente aandag skenk ten einde 'n oordeel uit te spreek oor die gehalte van die vertaling. Sodoende kan 'n bydrae gelewer word tot: (1) die veld van vertaalkritiek waarin daar nog weinig navorsing van hierdie presiese aard bestaan, en geen met betrekking tot Suid-Afrika gevind kon word nie, en (2) die Suid-Afrikaanse resensiebedryf deur 'n grondslag te lê vir verdere navorsing vir die ontwikkeling van 'n model vir die resensering van vertaalde werke (Paloposki 2012: 189).

Met hierdie studie word daar dus gepoog om die volgende navorsingsvrae te beantwoord:

1. Kom die internasionale tendens dat vertaalde werke geresenseer word sonder om te noem dat ' $n$ werk 'n vertaling is, ook binne die Afrikaanse en Suid-Afrikaanse Engelse literêre sisteme voor?

2. Aan watter (tegniese) aspekte van vertalings skenk resensente aandag ten einde 'n oordeel uit te spreek oor die gehalte van die vertaling?

\subsection{Metodologie}

\subsubsection{Navorsingsontwerp}

In hierdie studie is daar van longitudinale data, te wete resensies, gebruik gemaak wat deur middel van aanlynargiewe ${ }^{4}$ verkry is ten einde tendense in 'n tienjaartydperk (2006-2015) te kan bespeur. Eerstens is 'n lys saamgestel van alle vertaalde romans, insluitende jeugromans, met Afrikaans en Engels as taalpaar wat gedurende 2006-2015 in Suid-Afrika gepubliseer is. 'n Totaal van 150 titels is geïdentifiseer. Daarna is resensies van hierdie werke ingesamel om die datastel vir hierdie ondersoek te vorm. Die resensies het in/op een van die volgende vyf gedrukte/digitale publikasies en aanlynplatforms verskyn: Beeld, Die Burger, LitNet, Netwerk24 en News24 (met inhoud uit onder meer City Press en The Witness). Die datastel het uiteindelik uit 49 resensies bestaan.

Die resensies is ontleed met behulp van 'n meetinstrument (sien afdeling 3.3.2), naamlik 'n lys bestaande uit vyf vrae. ${ }^{5}$ Hierdie vrae is ontwikkel met die doel om die navorsingsvrae soos in afdeling 3.2 uiteengesit te beantwoord. ${ }^{6}$ Die gebruik van 'n meetinstrument stel ons in staat om

\footnotetext{
${ }^{4}$ Let wel: Media24 se aanlynargief is sedert omstreeks Junie 2016 nie meer aan die publiek beskikbaar nie en dus is die resensies se verskafde hiperskakels nie meer geldig nie.

${ }^{5}$ In die groter navorsingsprojek waarop hierdie artikel gebaseer is, het die meetinstrument nege vrae beslaan. Vir die doeleindes van hierdie artikel fokus ons hier op die vyf belangrikste vrae.

${ }^{6}$ Daar is nie aandag geskenk aan die visuele materiaal soos foto's van boeke wat dikwels by resensies ingesluit word nie omrede Media24 se argiefmateriaal nie die visuele materiaal insluit wat oorspronklik saam met 'n teks verskyn het nie.
} 
die ontleding van die data (die resensies) sistematies en konsekwent uit te voer, en ook om struktuur en eenvormigheid aan die aanbieding van die ontleding te verleen en sodoende die herhaalbaarheid van die studie te verhoog.

'n Beskrywende benadering is tydens data-analise gevolg: Met ander woorde, die inhoud van die resensies word beskryf sonder om voor te skryf hoe dit eerder moes lyk. Hierdie benadering is om twee redes geskik: Eerstens aangesien daar voldoende navorsing bestaan wat as teoretiese grondslag vir hierdie ondersoek kan dien (Bless, Higson-Smith en Sithole 2013: 61), en tweedens omdat beskrywende vertaalstudie op kommunikatiewe, sosiale en kulturele praktyke fokus, en die posisie van vertalings binne die doeltaalsisteem voorop stel (Toury 1995: 12, Schäffner 1995). Laasgenoemde aspek is relevant siende dat resensies juis vanuit die oogpunt van die doeltaalsisteem geskryf word.

\subsubsection{Meetinstrument}

Soos reeds genoem is die meetinstrument gebruik om die 49 resensies wat ingesamel is, konsekwent te ontleed om sodoende die navorsingsvrae te beantwoord. Die meetinstrument maak voorsiening vir kwantitatiewe sowel as kwalitatiewe data. Die vyf vrae waaruit die meetinstrument bestaan, toets byvoorbeeld kwantitatief watter persentasie van die teks in elke resensie aan die vertaling of vertaler gewy word (vergelyk onder andere vraag vyf hier onder), en kwalitatief of die teks wel as 'n vertaling geïdentifiseer word, waar dit gedoen word (indien wel), met watter woorde, ensovoorts (vergelyk vrae een tot vier).

'n Gemengde metodologie word dus gebruik, in ooreenstemming met Saldahna en O'Brien (2013: 201), wat aanvoer dat 'n kombinasie van kwantitatiewe en kwalitatiewe metodes besonder geskik is om sekere navorsingsvrae binne die veld van vertaalstudie te beantwoord. Die kombinasie van hierdie twee soorte metodes word volgens Saldahna en O'Brien (2013: 201) beskou as 'n manier om die beste aspekte van elk van hierdie paradigmas te kombineer, en om terselfdertyd hulle tekortkominge te hanteer. Gemengde metodes is volgens hulle byvoorbeeld besonder nuttig wanneer die navorsingsvrae gerig is op beide die aard van 'n verskynsel (die kwalitatiewe dimensie) en die verspreiding daarvan (die kwantitatiewe dimensie). In hierdie studie wil ons die resensente se werklike, talige verwysings na die vertaaldheid van die werk ontleed (die kwalitatiewe aspek) asook die verspreiding of voorkoms daarvan in resensies (die kwantitatiewe aspek).

Die vyf vrae waaruit die meetinstrument bestaan, is as volg:

\begin{tabular}{|l|l|l|}
\hline Vraagnommer & Vraag & Tipe data \\
\hline Vraag 1.1 & Word die teks as 'n vertaling geïdentifiseer? & Kwantitatief \\
\hline Vraag 1.2 & Indien wel, waar in die resensie? & Kwantitatief \\
\hline Vraag 2 & $\begin{array}{l}\text { Watter woorde/frases/sinne word gebruik om aan te dui dat die } \\
\text { teks 'n vertaling is? }\end{array}$ & Kwalitatief \\
\hline Vraag 3.1 & Kom die vertaler ter sprake? & Kwantitatief \\
\hline Vraag 3.2 & Indien wel, wat word genoem? & Kwalitatief \\
\hline Vraag 4.1 & Word die vertaling as sodanig beoordeel? & Kwantitatief \\
\hline Vraag 4.2 & $\begin{array}{l}\text { Indien wel, watter aspekte word uitgelig en watter } \\
\text { woorde/frases/sinne word gebruik om die vertaling te } \\
\text { beoordeel? }\end{array}$ & Kwalitatief \\
\hline
\end{tabular}




\begin{tabular}{|l|l|l|}
\hline Vraag 5 & $\begin{array}{l}\text { Watter persentasie van die resensie hou verband met die } \\
\text { vertaling/vertaler? }\end{array}$ & Kwantitatief \\
\hline
\end{tabular}

In die afdeling wat volg word die benadering tot en spesifieke toepassing van elke vraag saam met die resultate van die betrokke vraag in meer besonderhede bespreek.

\section{Resultate en bespreking}

In hierdie afdeling word die resultate aangebied deur die data wat na aanleiding van die vyf vrae vir elke individuele resensie ingesamel is, saam te vat. Daar word ook verwys na die aantal geresenseerde vertalings in vergelyking met die beraamde hoeveelheid vertaalde romans wat in die tydperk gepubliseer is. Hierdie inligting word gebruik om die navorsingsvrae in die slotafdeling te beantwoord. Tendense wat uit die data sigbaar raak, word ook uitgewys en bespreek aan die hand van die teoretiese raamwerke wat in die literatuuroorsig aan bod gekom het.

\subsection{Resultate en bespreking: Vraag 1}

\begin{tabular}{|l|l|l|}
\hline Vraagnommer & Vraag & Tipe data \\
\hline Vraag 1.1 & Word die teks as 'n vertaling geïdentifiseer? & Kwantitatief \\
\hline Vraag 1.2 & Indien wel, waar in die resensie? & Kwantitatief \\
\hline
\end{tabular}

Hierdie vraag fokus eerstens op die teenwoordigheid van 'n aanduiding dat die teks wat geresenseer word 'n vertaling is, en tweedens op die plek in die resensie waar sodanige aanduiding voorkom, indien wel. Ons fokus hier op die eerste woord, frase of $\sin$ in die resensie ${ }^{7}$ wat aan die leser bekend maak dat die boek 'n vertaling is. Om konsekwent te vergelyk waar in 'n resensie hierdie inligting genoem is, het ons vyf moontlike plekke (oftewel dele van 'n resensie) geïdentifiseer, te wete die hoofopskrif, die boekbesonderhede, die begin (in die inleidende paragraaf/paragrawe), die middel (in die lyfgedeelte) en die einde (in slotparagraaf of slotparagrawe) van die resensie. Vraag 1 verteenwoordig dus die kwantitatiewe komponent van die meetinstrument, aangesien die resultate kwantifiseerbaar en grafies voorstelbaar is.

Vraag 1.1 verskaf reeds 'n antwoord op die eerste navorsingsvraag, naamlik of die internasionale tendens om vertaalde werke as "oorspronklike" werke te resenseer ook plaaslik te bespeur is. Die antwoord blyk grootliks "nee" te wees, siende dat daar in slegs tien van die 49 resensies, oftewel $20,4 \%$, geensins genoem is dat die teks onder bespreking 'n vertaling is nie en dus die illusie skep dat daardie tekste "oorspronklike" werke is. Met ander woorde, in die ander 39 resensies - meer as 'n driekwart $(79,6 \%)$ - is daar op die een of ander stadium daarvan melding gemaak, hetsy baie direk of ietwat indirek, dat die teks 'n vertaling is. Op grond van laasgenoemde blyk dit dus dat die vertaler in die konteks van Afrikaanse en SuidAfrikaanse Engelse vertaalde romans nie juis “onsigbaar" (Venuti 1995, 2008) is nie en wel erkenning ontvang vir hulle rol in die skep van 'n teks.

\footnotetext{
${ }^{7}$ Met betrekking tot woordtelling, is die volgende in hierdie ondersoek as deel van 'n resensie beskou: die hoofopskrif, insluitende kategoriseringswoorde heel bo-aan soos "Resensie"/"Book review" en "Fiksie"/"Fiction" en die boekbesonderhede. Met betrekking tot woordtelling is die volgende in hierdie ondersoek nie as deel van 'n resensie beskou nie: die resensent se naam en van en die besonderhede oor die resensent wat langsaan die naam en van verskyn, asook die datum en/of tyd waarop die resensie verskyn het.
} 


\section{Word die teks as 'n vertaling geïdentifiseer?}

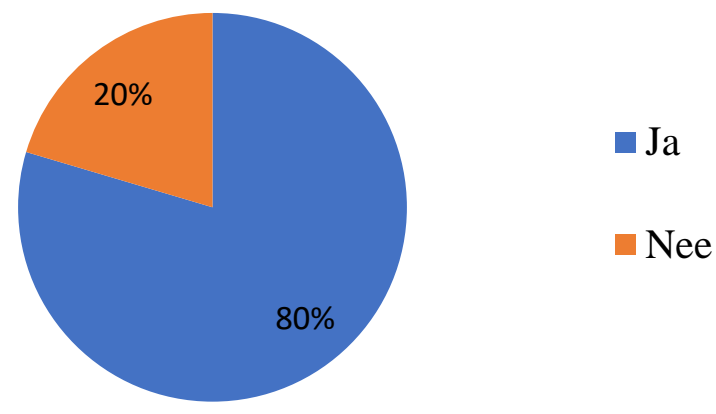

Figuur 1. Die resultate van vraag 1.1

Met verwysing na die tien resensies waarin daar geen melding van die vertaling gemaak is nie, is dit opvallend dat dit so te sê slegs op een mediaplatform plaasgevind het, te wete News 24 (agt uit die tien resensies). Die betrokke resensies is in Engels geskryf met Engelssprekendes as teikenmark (gegewe dat die betrokke boeke vertalings vanuit Afrikaans in Engels is) deur resensente wie se eerste taal moontlik Engels is. Hierdie tendens spreek dus onses insiens van een van die kwelpunte wat Venuti $(1995,2008)$ aan die hand van sy term "onsigbaarheid" illustreer, te wete dat vertaling ' $n$ randposisie in die Anglo-Amerikaanse literêre tradisie beklee - dit wil sê, in Engelssprekende kontekste. Met ander woorde, vertaaldheid blyk inderdaad wel juis "onsigbaar" te wees in hierdie Engelse resensies vir Engelssprekendes deur Engelssprekendes in teenstelling met Afrikaanse resensies vir Afrikaanssprekendes deur Afrikaanssprekendes. Onses insiens hou hierdie verskynsel ook verband met Munday (2001: 155) se mening dat ' $n$ spesifieke publikasie se beperkinge ten opsigte van resensielengte veral negatiewe gevolge vir resensies van vertalings inhou deurdat verwysings na die vertaling dikwels eerste uit resensies gesny word. Hierdie veronderstelling word ondersteun daardeur dat die News24-resensies, wat nie van vertaling melding maak nie, inderdaad veel korter as al die ander publikasies/platforms se resensies is - ondanks die feit dat dit ' $n$ aanlynmedium is.

Met verdere verwysing na spesifiek die 39 resensies waarin daar wel daarvan melding gemaak is dat die teks onder bespreking ' $n$ vertaling is, kan daar verdere afleidings gemaak word oor die (ware) aard van die vertaler se sigbaarheid deur die plasing van die verwysings na vertaaldheid in ag te neem. Dit was die doelstelling met vraag 1.2. Daar is spesifiek gekyk na waar in die resensie die resensent vir die eerste keer die leser se aandag daarop gevestig het dat die teks ' $n$ vertaling is (sien onderstaande grafiek). In agt van die 39 resensies (20,5\%) het die vertaaldheid van die teks reeds in die opskrif/titel aan bod gekom en in sewe van die resensies $(17,9 \%)$ is die vertaaldheid in die boekbesonderhede aangedui. Die boekbesonderhede verskyn onder die opskrif en bo die bespreking van die teks, maar is dikwels in 'n kleiner lettergrootte as in beide die ander dele. In nagenoeg die helfte van die resensies (19) (48,7\%) is die vertaaldheid van die teks in die inleidende paragrawe van die resensie ingewerk, in slegs een geval het dit in die middel (die lyfgedeelte) ter sprake gekom en in vier gevalle $(10,3 \%)$ is die vertaaldheid eers in die slotparagrawe genoem. 


\title{
Waar in die resensie is vertaaldheid aangedui?
}

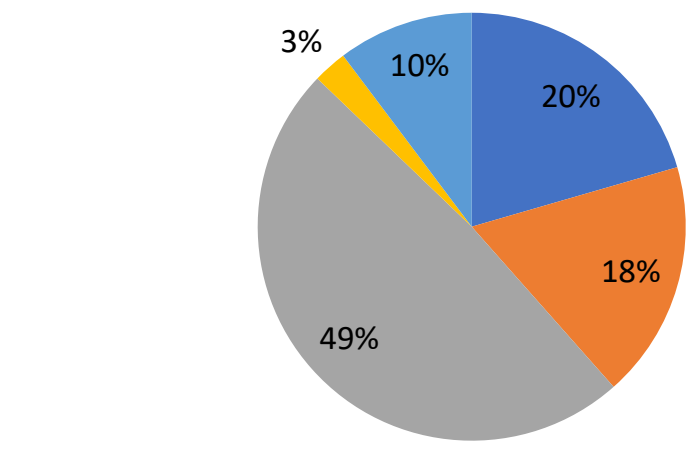

\author{
- Opskrif
}

Boekbesonderhede

- Inleiding

Lyf (Middel)

- Slot

Figuur 2. Die resultate van vraag 1.2

Gegewe dat ' $n$ teks van bo na onder gelees word, is die plasing van die eerste verwysing na die vertaaldheid van die teks baie belangrik aangesien dit beïnvloed hoe sigbaar hierdie inligting werklik is. Hierdie aspek is dan ook van besondere belang binne die konteks van die lees van resensies as mediapublikasies aangesien lesers onses insiens hier tipies hoofopskrifte vluglees en na aanleiding daarvan verder lees of nie. Op grond van bogenoemde persentasies kan daar dus gesê word dat die vertaaldheid van die meerderheid tekste in hierdie data inderdaad baie sigbaar is. Die opskrifte van resensies, soos bo genoem, word soms nie deur die resensent geskryf nie, maar deur die redaksiespan van die publikasie waarin dit verskyn. Hierdie aspek skakel na ons mening ook met die beperkende en manipulerende sosio-kulturele magte wat op herskrywings inwerk - in hierdie geval die ideologiese komponent van die patronaat deurdat die een of ander opvatting oor vertaling sal veroorsaak dat dit beklemtoon word al dan nie. Hierdie aspek blyk tot 'n mate uit die data aangesien ses uit die sewe opskrifte waarin vertaaldheid aanwesig was op Afrikaanssprekende lesers gemik was. Met ander woorde, soos bo genoem, geniet vertaling moontlik nie hoë status in Engelse kontekste nie. Daar blyk egter geen verdere tendense ten opsigte van taalrigting en die posisie van die eerste verwysing na vertaaldheid te wees nie.

Die noem van vertaaldheid in die boekbesonderhede erken onses insiens die rol van die vertaler in die skep van 'n teks en nie net dié van die skrywer nie. Die vertaler word meestal tussen hakies aangedui langs die skrywer se naam, wat weer na ons mening skakel met Venuti se siening dat vertaling ' $\mathrm{n}$ randposisie in die sisteem beklee siende dat inligting wat tussen hakies gegee word die konnotasie het dat dit nie noodsaaklik, belangrik of primêr is nie, maar as 'n nagedagte bygevoeg is. In aansluiting hierby spreek die noem van vertaaldheid in die slotparagrawe van 'n resensie, alhoewel dit in die minderheid is, na ons mening van twyfelagtige sigbaarheid en potensiële onsigbaarheid aangesien lesers moontlik kan ophou lees voor daardie inligting bereik word. Hierdie aspek dui onses insiens ook op die resensent se houding ten opsigte van hoe belangrik hierdie inligting is aangesien die noem van vertaaldheid in 'n slot, soos bo genoem, as 't ware as 'n nagedagte funksioneer. Lesers kan dit ook só interpreteer en moontlik hierdie houding teenoor vertaaldheid inneem wat dan, soos uitgewys deur Leech (2005: 12) en Venuti (2008: 13) en reeds bespreek, negatiewe gevolge vir die status van vertaaldheid kan inhou. 


\subsection{Resultate en bespreking: Vraag 2}

\begin{tabular}{|l|l|l|}
\hline Vraagnommer & Vraag & Tipe data \\
\hline Vraag 2 & $\begin{array}{l}\text { Watter woorde/frases/sinne word gebruik om aan te dui } \\
\text { dat die teks 'n vertaling is? }\end{array}$ & Kwalitatief \\
\hline
\end{tabular}

Met hierdie vraag fokus die meetinstrument op hoe 'n teks as 'n vertaling geïdentifiseer word. Ter beantwoording van die vraag word daar gesoek na enige woord, frase of sin in die hele resensie wat die leser daarvan bewus kan maak dat die boek 'n vertaling is. Gedurende die optekening van die antwoorde is die relevante woorde/frases/sinne telkens uit die resensie aangehaal: Individuele woorde en kort frases is egter dikwels nie in isolasie aangehaal nie, maar ter wille van verstaanbaarheid aangedui deur dit in ' $n$ sin of ' $n$ frase te onderstreep. Indien presies dieselfde relevante woorde/frases/sinne meer as een keer gebruik is, is dit slegs een keer aangehaal en uitgewys. Vraag 2 vorm dus deel van die kwalitatiewe komponent van die meetinstrument.

Aangesien woorde bepaalde konnotasies het, verskaf die manier waarop daar aangedui word dat ' $n$ teks ' $n$ vertaling is, na ons mening waardevolle kwalitatiewe inligting oor die samelewing se opvattings oor vertaling sowel as oor die status van vertaling en vertalers. Die gebruik van bepaalde woorde of fraserings hou dus verband met Venuti se term "onsigbaarheid" en hierdie woordkeuses skakel ook met die mag waaroor resensente volgens Lefevere (1992: 2) beskik om ' $n$ bepaalde gemanipuleerde beeld van 'n teks aan die publiek oor te dra en sodoende die kanonisering van 'n vertaalde teks te beïnvloed.

Op grond van die data (die 39 resensies waarin die teks wel as ' $n$ vertaling geïdentifiseer is), kan die vertaaldheid van 'n teks in die eerste instansie afgelei word uit die gebruik van die woorde "vertaal"/"translated" of "vertaling"//translation". Dit is uiteraard 'n baie direkte aanduiding van vertaaldheid en dus is dit baie opvallend dat een of meer variasie of verbuiging van hierdie woorde in elk van die 39 resensies gebruik is. Dit blyk dus dat resensente dit nie nodig ag om die vertaaldheid te verdoesel nie, wat na ons mening suggereer dat, in teenstelling met Venuti se waarneming in Engelssprekende lande, vertaling nie volgens die betrokke resensente ' $n$ randposisie in die Suid-Afrikaanse samelewing en die literêre sisteem beklee nie. Dit is egter nodig om in ag te neem dat die oorgrote meerderheid van die 39 resensies wat hier ter sprake is in Afrikaans vir Afrikaanssprekendes geskryf is en dat die meerderheid van die Engelse resensies wat wel hier ter sprake is op LitNet verskyn het - 'n platform wat ten eerste op Afrikaanssprekendes, wat tipies Engels magtig is, gemik is en daarom potensieel ook hulle ideologiese en literatuurbeskouinge in ag neem (Lefevere 1992: 15-16). Hierdie aspek sluit aan by die afleidings wat hierbo gemaak is, naamlik dat daar 'n meer positiewe gesindheid teenoor vertaling onder Afrikaanssprekendes as Engelssprekendes is.

Die vertaaldheid van 'n teks kon in die tweede instansie maklik afgelei word vanuit die gebruik van die woord "Afrikaans(e)" (of iets in dier voege) in 'n Engelse resensie en die woord "Engels(e)" (of iets in dier voege) in 'n Afrikaanse resensie. Hierdie woorde word tipies gebruik met verwysing na die skrywer van die teks (spesifiek die taal waarin hy/sy skryf) en/of met verwysing na die taal van die bronteks, byvoorbeeld "translated from Afrikaans" en "first published in Afrikaans", of die vertaling, byvoorbeeld "die Afrikaanse vertaling van". 
Voorbeelde ${ }^{8}$ van verwysings na die skrywer wat in die resensies bespeur is, sluit onder meer die volgende in: "a well-known writer in Afrikaans circles", "Afrikaans literary titan, Chris Barnard", "He writes in Afrikaans", "His novels are first published locally in Afrikaans" en "Sy is 'n psigoanalis [...] wat eintlik in Engels skryf". Die keuse tussen die gebruik van "uit Afrikaans/Engels vertaal" of "in Afrikaans/Engels vertaal" is na ons mening belangrik aangesien eersgenoemde klem op die bronteks en -taal plaas, terwyl laasgenoemde die klem na die vertaling en doeltaal verskuif. Alhoewel 'n noemenswaardige voorkeur vir een van hierdie fraserings nie uit die data blyk nie, is dit tog onses insiens 'n aanduiding van die mag waaroor herskrywers beskik aangesien hulle woordkeuses op hierdie subtiele manier potensieel die publiek se persepsies oor die belangrikheid van vertalings teenoor die bronteks kan beïnvloed, byvoorbeeld dat vertalings ondergeskik aan brontekste is. In aansluiting hierby is daar dan ook, soos bo genoem, 'n neiging om die vertaaldheid van ' $n$ teks in terme van die bronteks se titel en die skrywer (eerder as die vertaler) aan te dui wat op Venuti se "onsigbaarheid" van die vertaler dui.

\subsection{Resultate en bespreking: Vraag 3}

\begin{tabular}{|l|l|l|}
\hline Vraagnommer & Vraag & Tipe data \\
\hline Vraag 3.1 & Kom die vertaler ter sprake? & Kwantitatief \\
\hline Vraag 3.2 & Indien wel, wat word genoem? & Kwalitatief \\
\hline
\end{tabular}

Ter beantwoording van hierdie vraag word daar in die hele resensie gekyk of die vertaler by die naam genoem word, al dan nie, asook na watter woorde gebruik word om die vertaler te benoem - byvoorbeeld of ekstra inligting oor die vertaler verskaf word. Vraag 3.1 vorm deel van die kwantitatiewe komponent en vraag 3.2 van die kwalitatiewe komponent van die meetinstrument.

Vraag 3 hou ook verband met Venuti se beskouinge oor die "onsigbaarheid" van vertaling en spesifiek van die vertaler. Daar is in 27 van die 49 resensies $(55,1 \%)$ melding gemaak van die vertaler as sodanig, terwyl daar in die ander $22(44,9 \%)$ glad nie na die vertaler verwys is nie (sien onderstaande grafiek). Dit is verder opvallend dat die vertaler in 21 van die eersgenoemde 27 gevalle $(77,8 \%)$ by name genoem is. Hierdie persentasies kan vergelyk word met die data wat vir vraag een verkry is ten einde te bepaal hoe sigbaar die vertaler is en nie net die vertaalhandeling nie. Met ander woorde, vertalers as sodanig is in 55,1\% van die data sigbaar alhoewel die vertaaldheid van tekste in $79,6 \%$ van die data sigbaar is. Dit strook met Morgan se beskrywing van vertalers as "die skadufigure agter vertaalde werke" [...] "wie se name by min mense bekend is" (in Britz 2016).

\footnotetext{
${ }^{8}$ Weens beperkinge in terme van plek en kopiereg is dit nie moontlik om die resensies self as deel van die studie aan te bied nie. Ons bespreek deurgaans dus enkele relevante voorbeelde uit die resensies wat ons ontleed het.
} 


\section{Kom die vertaler ter sprake?}

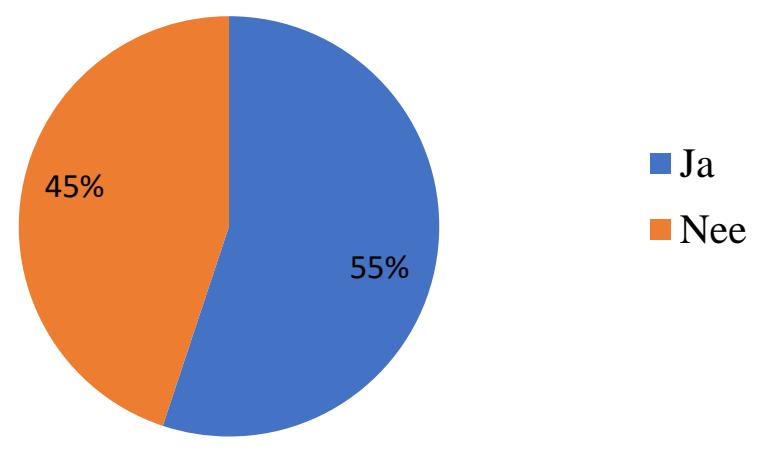

Figuur 3. Die resultate van vraag 3.1

Hierdie beperkte sigbaarheid van spesifiek die vertaler skakel direk met Lefevere se beskouing van resensente as herskrywers. Deur nie die vertaler by die naam te noem nie, tree die resensent as die fasiliteerder van die vertaler se onsigbaarheid op en so word ' $n$ gemanipuleerde beeld aan die publiek oorgedra. Hierdie onsigbaarheid misken vertalers se rol in die skep van die teks sowel as hulle openbare status, aangesien dit indirek aan die publiek kommunikeer dat vertalers nie belangrik genoeg is om by name genoem te word nie. Hierdie beperkte sigbaarheid in die media kan byvoorbeeld veroorsaak dat vertalers (verder) gemarginaliseer word. Dit kan negatiewe implikasies inhou vir onder meer die kanonisering van vertaalde romans sowel as vir die vertaalprofessie aangesien dit daartoe kan lei dat jongmense nie in die beroep belangstel nie of dat mense nie eens van die professie bewus is nie (Leech 2005: 12, Venuti 2008: 13; vergelyk McLaughlin 2008). Dit is na ons mening weereens belangrik om in ag te neem dat herskrywings egter ook aan beperkende en manipulerende sosio-kulturele magte onderworpe is. Soos genoem, wys Munday (2001: 155) daarop dat 'n betrokke publikasie se beperkinge ten opsigte van resensielengte veral negatiewe gevolge vir resensies van vertalings inhou deurdat verwysings na die vertaling en die vertaler dikwels eerste uit resensies gesny word. Dit kan onses insiens stam uit 'n opvatting dat vertaling 'n sekondêre posisie teenoor die bronteks beklee, wat dus weer eens dui op Venuti se beskouing van die rol en posisie van vertaling in die samelewing.

Met verwysing na die 27 resensies waarin die vertaler wel genoem is, was dit tipies slegs by name, hetsy in die boekbesonderhede, inleiding, lyf of slot, - dit wil sê, sonder om oor die vertaler uit te brei en sodoende meer fokus op hulle te plaas. Dit is egter opvallend dat die vertalers tipies in die boekbesonderhede tussen hakies langs die skrywer genoem word - en dus onses insiens 'n sekondêre posisie inneem. Daar is net in enkele gevalle ook op die vertalers uitgebrei, hoofsaaklik op een van twee wyses, naamlik deur die vertaler op 'n manier te "beskryf" en/of deur te verwys na hulle vertaalvermoë, waaronder ook deur die gee van 'n kompliment ten opsigte hiervan, byvoorbeeld "puik vertaler", "Heyns has not disappointed in his role as translator" en "Heyns has vividly brought the novel to life in English". Die "beskrywings" hou tipies verband met die persoon se status of bekendheid as vertaler, byvoorbeeld "heavyweight translator" en "die bekende Konsalik-vertaler". 


\subsection{Resultate en bespreking: Vraag 4}

\begin{tabular}{|l|l|l|}
\hline Vraagnommer & Vraag & Tipe data \\
\hline Vraag 4.1 & Word die vertaling as sodanig beoordeel? & Kwantitatief \\
\hline Vraag 4.2 & $\begin{array}{l}\text { Indien wel, watter aspekte word uitgelig en watter } \\
\text { woorde/frases/sinne word gebruik om die vertaling te } \\
\text { beoordeel? }\end{array}$ & Kwalitatief \\
\hline
\end{tabular}

Met hierdie vraag is die doel om in die hele resensie te bepaal of daar spesifiek 'n oordeel uitgespreek word oor die gehalte van die vertaling, byvoorbeeld deur die woord "vlot" te gebruik, en of daar spesifiek aandag geskenk word aan die vertaalproses, byvoorbeeld die vertaalkeuses wat gemaak is en die geslaagheid daarvan al dan nie. Vraag 4.1 vorm deel van die kwantitatiewe komponent en vraag 4.2 van die kwalitatiewe komponent van die meetinstrument.

Vraag 4 skakel met twee tendense waarna daar in die inleiding reeds verwys is. Eerstens die mening van kenners soos Reiss (2000: 2) dat resensies van vertaalde werke dikwels nie sodanige werke as vertalings beoordeel nie. Wanneer hulle dit wel doen, meen Reiss, word daar gereeld van cliché-agtige frases gebruik maak, soos byvoorbeeld "vloeiende vertaling", "lees vlot". Venuti se mening dat "vloeiende" vertalings deur die meeste uitgewers, resensente en lesers met geslaagdheid en aanvaarbaarheid vereenselwig word, kom dus hier ter sprake. Vertalings, aldus Venuti (2008: 5) is vloeiend wanneer hulle so te sê geen blyke van die vertaalproses toon nie en net soos die oorspronklike lees. Die data wat in hierdie studie verkry is, blyk egter nie hierdie twee waarnemings ten volle te ondersteun nie.

In die eerste plek is daar slegs in ietwat meer as die helfte van die resensies wel aandag geskenk aan die vertaling as sodanig, te wete 27 uit die 49 resensies (oftewel 55,1\%) (sien die onderstaande grafiek). Met "vertaling as sodanig" word daar bedoel aspekte soos vertaalkeuses en/of waarde-oordele wat oor die gehalte van die vertaling as "goed" of "sleg" gemaak word. Hierdie bevinding bied dus slegs ' $n$ mate van bevestiging dat daar ' $n$ neiging is om vertalings nie as sodanig te resenseer nie, maar eerder as "oorspronklike" werke. Dit is egter hier belangrik om daarop te let dat die gebrekkige bespreking van die vertaling as sodanig die gevolg van publikasies se lengtebeperkinge op resensies kan wees (vergelyk die bespreking van vraag 1). 


\section{Is die vertaling as sodanig beoordeel?}

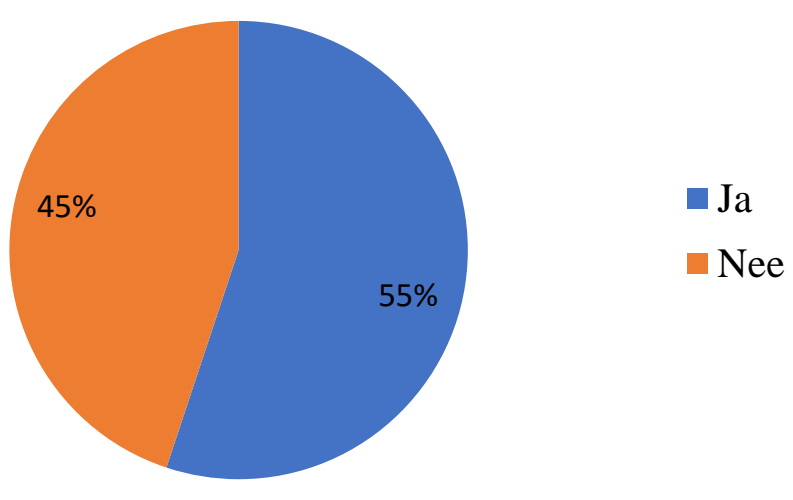

Figuur 4. Die resultate van vraag 4.1

In die tweede plek strook die taalgebruik in die data met Reiss (2000: 1) se waarneming aangesien woorde wat gebruik is om vertalings te beoordeel/beskryf onder meer die volgende insluit: "puik", "knap", “(oorwegend) vlot", "uitstekend", "worthy" en "lovely". Reiss (2000: 1) meen verder dat resensies van vertalings dikwels breë stellings maak oor die gehalte van 'n vertaling sonder om sodanige uitsprake te motiveer. In teenstelling met Reiss toon ons data egter dat waar "generiese" uitsprake in die resensies wat ondersoek is, voorkom, hulle wel meestal geregverdig word deur op spesifieke aspekte van die vertaling te wys.

Met betrekking tot die aspekte van die vertaling waaraan resensente aandag skenk, is daar drie wat besonder dikwels na vore kom: Eerstens die aard en gepastheid van die taalgebruik, onder meer in terme van styl, register (die gebruik van 'n streeksvariëteit) en idiomatisiteit (byvoorbeeld "die dialoog sit tog lekker in die mond" en "lees lekker"); tweedens die betekenisimplikasies van bepaalde woordkeuses, en derdens, hoe die bronteks se titel met dié van die vertaling vergelyk (byvoorbeeld "dit is kort maar gepas" en "die Engelse titel [...] dra wel meer van die deernis van die storie oor"). Dit is verder opvallend dat resensente by uitstek fokus en uitbrei op wat die vertaler na hulle mening verkeerd of sleg hanteer het, maar net baie vlugtig na positiewe aspekte verwys en dan boonop selde voorbeelde van sulke aspekte uit die teks verskaf wat onses insiens van die manipulerende krag van herskrywings spreek. Met verwysing na die betekenisimplikasies van bepaalde woordkeuses, lys resensente dikwels 'n reeks voorbeelde van sogenaamde "vertaalfoute" of "vertaalglipse" - dit wil sê, waar die betekenis van 'n woord verander is as gevolg van woordkeuse. Dit is egter opvallend dat resensente tog nooit uitsluitlik op negatiewe aspekte wys nie.

\subsection{Resultate en bespreking: Vraag 5}

\begin{tabular}{|l|l|l|}
\hline Vraagnommer & Vraag & Tipe data \\
\hline Vraag 5 & $\begin{array}{l}\text { Watter persentasie van die resensie hou verband met die } \\
\text { vertaling/vertaler? }\end{array}$ & Kwantitatief \\
\hline
\end{tabular}


Om hierdie vraag te beantwoord, word die woorde in al die sinne ${ }^{9}$ in die resensie wat dui op die vertaaldheid van die boek bymekaargetel en deur die woordtelling van die hele resensie gedeel en dan na 'n persentasie omgeskakel. Sodoende kan 'n vergelyking getref word tussen resensies ondanks hulle verskillende lengtes. Hierdie data is dus weer kwantitatief.

Soos reeds genoem is daar in 39 uit die 49 resensies - byna $80 \%$ - daarna verwys dat die teks 'n vertaling is. Op grond van hiervan blyk dit dus dat die vertaler nie werklik "onsigbaar" (Venuti 1995,2008 ) is nie en wel erkenning ontvang vir hulle rol in die skep van 'n teks. Dit is egter ook belangrik om in ag te neem hoeveel ruimte aan bepaalde fasette van 'n resensie bestee word.

In laasgenoemde verband toon die data dat daar in die meeste van die resensies $(51,3 \%)$ slegs tussen $1 \%$ en $10,9 \%$ van die totale woordtelling aan die vertaaldheid van die teks bestee is. Slegs vyf resensies het dus grotendeels op vertaling gefokus. Met ander woorde, alhoewel dit blyk dat vertaaldheid nie in die besonder onsigbaar is nie, kan daar in die lig van hierdie inligting, te wete die hoeveel aandag wat aan vertaaldheid geskenk is, geargumenteer word dat vertaaldheid wel eerder na onsigbaarheid as sigbaarheid neig.

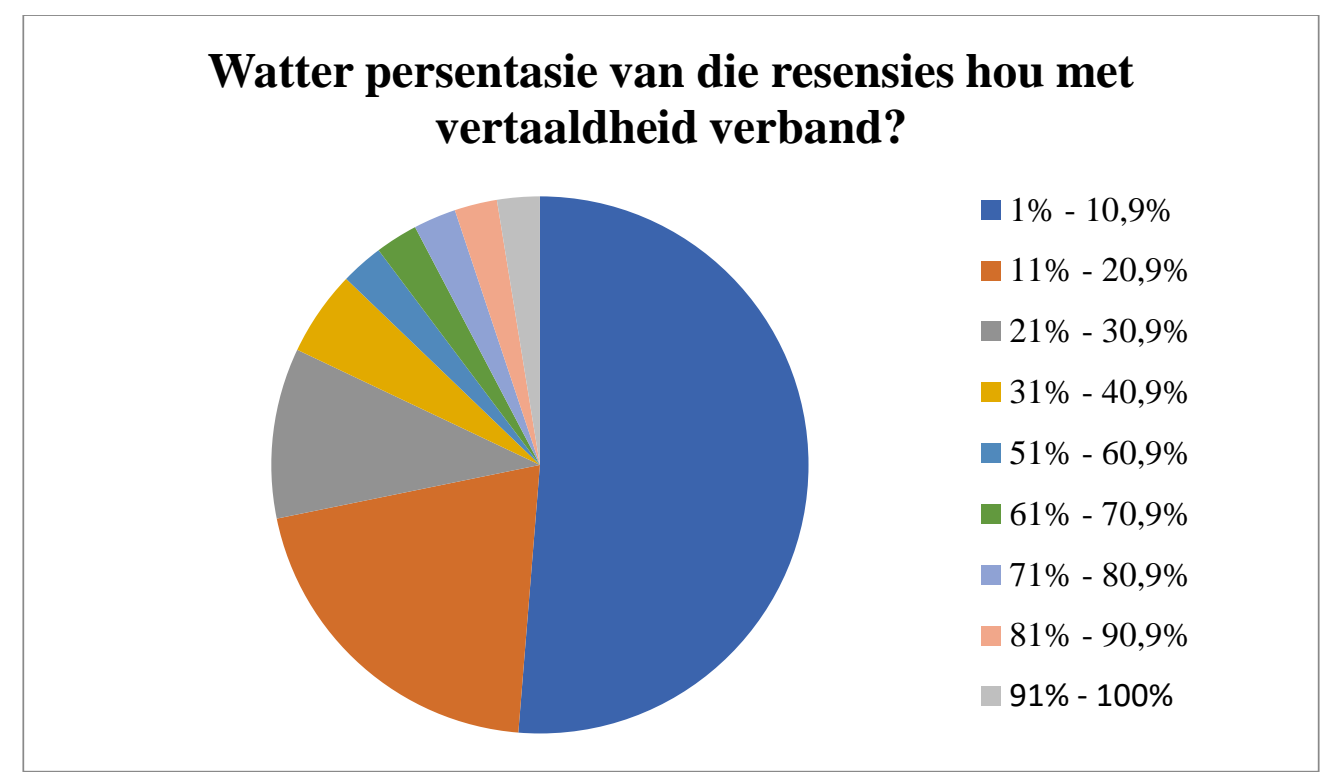

Figuur 5. Die resultate van vraag 5

Ook hier is dit egter belangrik om daarop te let dat resensies vanweë hulle klassifikasie as herskrywings ook aan beperkende faktore onderworpe is, insluitende lengte. Munday (2001: 155) voer aan dat laasgenoemde faktor negatiewe gevolge vir resensies van vertalings in besonder inhou omdat die dele van resensies wat oor die vertaling handel dikwels eerste deur die publikasie se redaksie uitgesny word. Aan die ander kant spreek Munday se opmerking weer eens van Venuti se siening dat brontekste hoër status geniet as vertalings. Die polisisteemteorie toon in hierdie verband dat gebrekkige erkenning in die media implikasies vir die kanonisering van vertalings het.

\footnotetext{
${ }^{9}$ Met ander woorde, individuele woorde en frases wat op vertaaldheid dui is nie as sodanig (in isolasie) getel nie, maar as deel van die woordtelling van die hele sin waarin dit voorkom.
} 


\section{Gevolgtrekking}

Die doelstelling met die eerste navorsingsvraag was om te ondersoek tot watter mate die vertaler en die vertaalhandeling sigbaar is in die resensies van vertaalde romans ten einde te bepaal of die internasionale tendens om vertaalde werke as "oorspronklike" werke te resenseer ook plaaslik in die Afrikaanse en Suid-Afrikaanse Engelse literêre sisteme voorkom. Die antwoord op laasgenoemde vraag blyk grootliks "nee" te wees. Hierdie afleiding is gebaseer op die bevindinge wat met betrekking tot die vrae in die meetinstrument verkry is. Die resultate toon dat daar in 79,6\% van die resensies wel aangedui word dat die teks onder bespreking 'n vertaling is. Op grond hiervan kan ons argumenteer dat die vertaler in hierdie opsig nie "onsigbaar" (Venuti 1995, 2008) is nie en wel erkenning ontvang, hetsy in 'n meerdere of 'n mindere mate, vir hulle bydrae. Aan die ander kant is daar bevind dat meer inligting oor vertalers as sodanig in slegs $55,1 \%$ van die data sigbaar is wat daarop dui dat vertalers inderdaad beskou kan word as "skadufigure agter vertaalde werke wie se name by min mense bekend is" (Morgan, in Britz 2016). Hierdeur tree resensente dan wel as fasiliteerders van vertalers se onsigbaarheid op en dra so 'n gemanipuleerde beeld aan die publiek oor.

Ten opsigte van die Afrikaanse teenoor die Engelse sisteem in Suid-Afrika is verskille opgelet, en vertaaldheid blyk juis eerder "onsigbaar" te wees in die Engelse resensies vir Engelssprekendes deur Engelssprekendes in teenstelling met Afrikaanse resensies vir Afrikaanssprekendes deur Afrikaanssprekendes.

Die posisie in die resensie waar vertaaldheid ter sprake kom, kan ook 'n aanduiding van die sigbaarheid van vertaaldheid gee, en aangesien dit in 48,7\% van die resensies in die inleidende paragrawe vermeld word, kan daar gesê word dat vertaaldheid heel sigbaar is.

Aan die ander kant is daar 'n neiging om die vertaaldheid van 'n teks in terme van die bronteks se titel en die skrywer (eerder as die vertaler) aan te dui, wat weer op onsigbaarheid dui. Ook is daar ' $n$ tendens om nie oor die vertaler uit te brei nie, en slegs sy/haar naam - en dan dikwels tussen hakies naas dié van die skrywer - te gee.

Uiteindelik word daar bevind dat alhoewel vertaaldheid nie as sodanig onsigbaar is nie, daar tog die tendens is dat vertaaldheid wel eerder na onsigbaarheid as sigbaarheid neig.

$\mathrm{Na}$ aanleiding van die totale aantal vertaalde romans wat tussen 2006 en 2015 gepubliseer is, te wete 150 tekste (vergelyk afdeling 3.3.1), blyk dit duidelik dat slegs 'n handjievol van daardie romans in hierdie datastel voorkom. Dit verskaf dus weer eens bevestiging vir Venuti se siening dat vertaling ' $n$ randposisie beklee en dit bied onses insiens rede tot kommer vanweë die sleutelrol wat resensering duidelik in die beeldvorming oor literatuur vervul.

Die doelstelling met die tweede navorsingsvraag was om te bepaal aan watter (tegniese) aspekte van vertalings resensente aandag skenk ten einde 'n oordeel uit te spreek oor die gehalte van die vertaling. Daar bestaan egter nie 'n model wat spesifiek op die resensies van vertalings van toepassing is wat hiervoor gebruik kon word nie. Nietemin stel die data wat ons uit die toepassing van die meetinstrument versamel het, ons in staat om 'n aantal afleidings te maak. In teenstelling met Reiss (2000: 2) se opmerking oor die resensering van vertalings toon hierdie data dat alhoewel resensente wel "generiese" uitsprake soos "knap" en "worthy" oor vertalings maak, dit wel oorwegend gesteun word deur op spesifieke (tegniese) aspekte van die vertaling te wys. 
Soos reeds genoem, was daar eerstens 'n voorkeur vir "fluency", soos aangevoer deur Venuti aangesien dit vanuit byna al die resensies geblyk het dat 'n maklik leesbare (en derhalwe gedomestikeerde) vertaling hoog op prys gestel word. Tweedens het resensente veral dikwels kommentaar gelewer ten opsigte van die volgende drie tekstuele aspekte van vertalings: (1) die gepastheid van die taalgebruik, waaronder in terme van styl, register en idiomatisiteit; (2) die betekenisimplikasies van bepaalde woordkeuses veral met verwysing na sogenaamde "vertaalfoute" of "vertaalglipse"; en (3) hoe die bronteks se titel met dié van die vertaling vergelyk. Laastens het resensente ook hulle oordele in 'n mindere mate gebaseer op die aard van die leeservaring wat die vertaling verskaf.

Met betrekking tot bogenoemde twee aspekte van resensies, blyk dit op grond van 'n aantal redes belangrik te wees om in ag te neem waar die resensies wat in hierdie datastel ondersoek is, gepubliseer is. In die eerste plek is daar bevind dat ruimtebeperkinge in gedrukte publikasies heel moontlik wel, soos aangevoer deur Lefevere, lei tot gebrekkige bespreking van die vertaaldheid van 'n teks of dat hierdie aspekte dalk wel eerste uit 'n resensie gesny word. Hierdie bevinding blyk uit die mate van aandag wat aan vertaaldheid gewy is in die resensies van veral LitNet in vergelyking met News24 (wat inhoud uit gedrukte publikasies bevat) wat onderskeidelik die langste en die kortste was in terme van woordtelling. In die tweede plek moet daar in ag geneem word dat 'n publikasie se teikengehoor die inhoud blyk te beïnvloed soos voorgestel deur onder meer die patronaat en ideologiese komponent van herskrywing.

Met hierdie studie is daar gepoog om by te dra tot, soos Paloposki (2007) dit stel, die "afgeskeepte veld" van vertaalkritiek, met spesifieke verwysing na die vraag of die globale tendens om vertalings as "oorspronklike" werke te resenseer ook plaaslik voorkom in die Afrikaanse en Suid-Afrikaanse Engelse literêre sisteme. Hierdie navorsing kan ook 'n grondslag lê vir verdere navorsing vir die ontwikkeling van 'n model vir die resensering van vertaalde werke soos voorgestel deur Paloposki (2012). Die belang van hierdie tipe navorsing is geïllustreer: Eerstens, met verwysing na resensering as 'n vorm van herskrywing, en dus manipulasie, wat nietemin as 'n prominente kanoniseringsmiddel funksioneer; en tweedens, deur op die problematiek van die "onsigbaarheid" van vertaaldheid in resensies te wys in die lig daarvan dat dit kan veroorsaak dat vertalers en vertalings (verder) gemarginaliseer word, byvoorbeeld ten opsigte van kanonisering, wat ook onder meer tot die kwyning van die vertaalprofessie kan lei (Leech 2005).

\section{Verwysings}

Bless, C., C. Higson-Smith en S.L. Sithole. 2013. Fundamentals of social research methods: An African perspective. Vyfde uitgawe. Lusaka: Juta.

Britz, E. 2016. Morgan vertel van 'skadufigure' agter vertaalde werke. [Intyds]. Beskikbaar: http://www.netwerk24.com/Vermaak/Boeke/morgan-vertel-van-skadufigure-agter-ver-taaldewerke-20160805 (8 September 2016).

Codde, P. 2003. Polysystem theory revisited: A new comparative introduction. Poetics Today 24(1): 91-126. https://doi.org/10.1215/03335372-24-1-91 
Emmerich, K.R. 2013. Visibility and invisibility. In Y. Gambier en L. Van Doorslaer (reds.) Handbook of translation studies. Volume 4. Amsterdam: John Benjamins. bll. 200-206. https://doi.org/10.1075/hts.4.vis1

Even-Zohar, I. 1990. Polysystem theory. Poetics Today 11(1): 9-51.

Fawcett, P. 2000. Translation in the broadsheets. The Translator 6(2): 295-308.

Geldenhuys, H. 2009. Tydskrifvertalers as Kulturele Bemiddelaars: Enkele Gevallestudies in Suid-Afrika. Ongepubliseerde Magistertesis. Universiteit Stellenbosch.

Gentzler, E. 2001. Contemporary translation theories. Tweede uitgawe. Clevedon: Multilingual Matters.

Hatim, B. 2001. Teaching and researching translation. Harlow: Longman.

Hermans, T. 1996. The translator's voice in translated narrative. Target 8(1): 23-48.

Hermans, T. 2009. Translation, ethics, politics. In J. Munday (red.) The Routledge companion to translation studies. Oxon: Routledge. 93-105.

Hokenson, J.W. en M. Munson. 2007. The bilingual text: History and theory of literary selftranslation. Manchester: St. Jerome.

Janssen, S. 1994. In het licht van de kritiek. Variaties en patronen in de aandacht van de literatuurkritiek voor auteurs en hun werken. Hilversum: Verloren.

Koskinen, K en O. Paloposki. 2003. Retranslations in the age of digital reproduction. Cadernos de Tradução 1(11): 19-38.

Lambert, J. 2010. Literary translation. In M. Baker en G. Saldanha (reds.) Routledge encyclopedia of translation studies. Derde uitgawe. Manchester: Routledge. bll. 130-133.

Leech, W. 2005. The Translator's Visibility: An Investigation into Public Perceptions of the Translator and How to Raise the Translator's Status in Society. Ongepubliseerde M-tesis. Universiteit van Londen.

Lefevere, A. 1985. Why waste our time on rewrites? The trouble with interpretation and the role of rewriting in an alternative paradigm. In T. Hermans (red.) The manipulation of literature: Studies in literary translation. New York: St. Martin's Press. https://doi.org/10.4324/9781315759029-12

Lefevere, A. 1992. Translation, rewriting, and the manipulation of literary fame. Londen: Routledge.

Lourens, A. 1997. Polemiek en Kanon: Kanonisering van die Vroulike Outeur in die Afrikaanse Prosa van die Dertiger- tot die Negentigerjare. Ongepubliseerde doktorale proefskrif. Universiteit van Pretoria. https://doi.org/10.4102/satnt.v18i1.714 
Maier, C. 2008. Reviewing and criticism. In M. Baker (red.) Routledge encyclopedia of translation studies. Tweede uitgawe. Manchester: Routledge. bll. 236-240.

McLaughlin, M. 2008. (In)visibility: Dislocation in French and the voice of the translator. French Studies 62(1): 53-64. https://doi.org/10.1093/fs/knm233

Moerbeek, J. 1992. Hoe elastisch is de canon? Spiegel der Letteren 34(2-3): 333-357. https://doi.org/10.2143/sdl.34.3.2005584

Munday, J. 2001. Introducing translation studies: Theories and applications. New York/Londen: Routledge.

Nord, C. 1991. Skopos, loyalty and translational conventions. Target 3(1): 91-109.

Paloposki, O. 2007. Translator's agency in 19th-century Finland. In Y. Gambier, M. Shlesinger en R. Stolze (reds.) Doubts and directions in translation studies. Philadelphia: John Benjamins. bll. 335-346. https://doi.org/10.1075/btl.72.32pal

Paloposki, O. 2012. Translation criticism. In Y. Gambier en L. Van Doorslaer (reds.) Handbook of translation studies. Volume 3. Amsterdam: John Benjamins. bll. 184-189. https://doi.org/10.7202/1018812ar

Palumbo, G. 2009. Key terms in translation studies. Londen: Continuum.

Reiss, K. 2000. Translation criticism - The potentials and limitations. Manchester: St. Jerome.

Roos, D. 2009. 'n Ondersoek na Afrikaanse Vertaalkenmerke in 'n Korpus Koerantberigte. Ongepubliseerde Magistertesis. Universiteit Stellenbosch.

Saldahna, G. en S. O’Brien. 2013. Research methodologies in translation studies. Manchester: St. Jerome.

Schäffner, C. 1995. Translation studies. In J. Östman, J. Verschueren, J. Blommaert en C. Bulcaen (reds.) Handbook of pragmatics. Philadelphia: John Benjamins. bll. 1-18. https://doi.org/10.1075/hop.1

Schulte, R. 2015. Translation criticism. [Intyds]. Beskikbaar: https://www.utdallas.edu/research/cts/essays/criticism_essay1.html (12 Februarie 2020).

Toury, G. 1995. Descriptive translation studies and beyond. Philadephia: John Benjamins.

Vanderschelden, I. 2000. Quality assessment and literary translation in France. The Translator 6(2): 271-294.

Venuti, L. 1995. The translator's invisibility: A history of translation. Oxon: Routledge.

Venuti, L. 2008. The translator's invisibility: A history of translation. Tweede uitgawe. Oxon: Routledge. 